\title{
Toxicity Test Toward Dichloromethane Fraction from White Frangipani Leaves (Plumeria alba)
}

\author{
Nurul Hidajati*, Qodriyah \\ Chemistry Department Faculty of Mathematic and Science \\ Universitas Negeri Surabaya \\ Surabaya, Indonesia \\ nurulhidajati@unesa.ac.id
}

\begin{abstract}
White frangipani (Plumeria alba) is a plan that is widely grown in Indonesia especially in Java and Bali. It has been conducted a research to know the chemical content of the plan leaf. The leaves of plant are extracted with dichloromethane solvent and then separated by using chromatographic techniques to obtain 4 combined fractions namely fraction $A, B, C$, and $D$. The chromatography results obtained 4 fractions namely A, B, C, and D. Except fraction D, after doing the phytochemical test, the three other fractions are known to be steroids. Using the same manner, fraction $D$ is known containing alkaloid. Fraction $D$ is then tested for knowing toxicity of it using BSLT method and resulted LC50 value to be $54,448 \mathrm{ppm}$.
\end{abstract}

Keywords - White frangipani, Plumeria alba, BSLT, Toxicity

\section{INTRODUCTION}

Frangipani is a type of flowering plants that are widely grown in Indonesia [2]. White frangipani including Apocynaceae family is known as one of medicinal plants in which leaves can be used as laxative and anti itch, fruit and stem bark can be used as anti-inflammatory [4]. Frangipani stems and leaves contain flavonoids and alkaloids and can be used as traditional medicine [3].

The chemical content of white frangipani include fulvoplumierin (antibacterial), in its essential oil there are compounds of eugenol, linalool, farsenol, geraniol, phenetolalcohol, and stigmasterol. It also contains serotonic acid, agoniadin, plumeric acid, plumerid, and lupeol [1]. In the hexane extract of the bark of the plant contains steroid, in dichloromethane extracts contain steroid and alkaloids compounds, whereas in the ethanol extract contain flavonoid compounds, tannins, saponins, alkaloids, phenolics, and steroids.

Toxicity study is a study method to examine the relevant effects on the biology system to determine the right dose. Toxicity is defined as drug parameters that can produce damage to living things. Brine Shrimp Lethality Test (BSLT) is a fast and inexpensive way to test a toxicity of samples using shrimp larvae Artemia salina Leach. by monitoring the mortality rate of the shrimp larvae.

\section{METHOD}

\section{A. Equipment}

Buchner funnel, Erlenmeyer flask, a set of Vacuum Liquid Chromatographic (VLC) tools, vacuum, rotary evaporator, micropipette, vial bottle, test tube, spatula.

\section{B. Material}

$2 \mathrm{~kg}$ of leaves white frangipani plant, VLC silica, sea water, Artemisia salina larvae, aquades, dichloromethane, DMSO, $\mathrm{HgCl}_{2}, \mathrm{KI}, \mathrm{Bi}\left(\mathrm{NO}_{3}\right)_{2}, \mathrm{HNO}_{3}, \mathrm{I}_{2}$, filter paper whatman, $\mathrm{HCl} 2 \mathrm{~N}$, acetic anhydrous, concentrated $\mathrm{H}_{2} \mathrm{SO}_{4}$, $\mathrm{FeCl}_{3} 1 \%, 70 \%$ ethanol, $\mathrm{Mg}$ band, concentrated $\mathrm{HCl}, \mathrm{HCl}$ $1 \mathrm{~N}, 10 \% \mathrm{NaCl}, 1 \%$ gelatin.

\section{Sample Preparation}

As much as $\pm 1 \mathrm{~kg}$ of dried powder of white frangipani leaves is macerated by using dichloromethane solvent for $1 \times 24$ hours and repeated 3 times to gain macerates. It was then concentrated using a vacuum rotary evaporator. \pm 20 grams of thickened extract. The extract is further separated by using VLC with hexane: ethyl acetate in graduating to yield 48 fractions. Baseed on VLC analysis, these fractions can further be combined to be four combined fractions, namely fraction A(1-15), B (16 - 30), C (31 - 37) and D (38 48). All of combined fractions was treated by phytochemical test to obtain the chemical components in each fractions as reported below.

\section{Phytochemical Test}

Phytochemical tests were performed on dichloromethane extract and fraction above.

\section{1) Flavonoid Test}

$1 \mathrm{~mL}$ sample is inserted into a drop plate, then added 0.1 gram of Magnesium band and 2 drops of concentrated hydrochloric acid. The positive test is marked by the appearance of red.

\section{2) Steroids and Triterpenoids Test}

$1 \mathrm{~mL}$ sample is inserted into the drop plate, added $\left(\mathrm{CH}_{3} \mathrm{CH}_{2}\right)_{2} \mathrm{O}$ and concentrated sulfuric acid. purple, orange, and golden yellow colors for triterpenoids meanwhile blue and green colors for steroids.

\section{3) Tanin Test}

$1 \mathrm{~mL}$ sample is inserted into the drop plate, added 1 drop of $10 \%$ sodium chloride, $1 \%$ gelatin and sodium chloride again. White sediments for tannin.

\section{4) Phenolic Test}

$1 \mathrm{~mL}$ sample is inserted into the drop plate then added 2 drops of 1 iron (III) chloride. Red, blue, green, red, purple, or solid black formed indicate a phenolic.

\section{5) Alkaloid Test}


$1 \mathrm{~mL}$ sample was inserted into the test tube and added $1 \mathrm{ml}$ of chloroform and $1 \mathrm{~mL}$ of ammonia, subsequently heated in a water bath. The next mixture is added 3 drops of $2 \mathrm{~N}$ sulfuric acid and is divided into 3 parts. Each mixed portion is added 3-drop test reagent of the Mayer reagent (yellow precipitate indicates positive test), 3 drops of Dragendorff reagent (red sediment indicates positive test), and 3 drops of Wagner reagent (brown or reddish deposition indicates positive test).

6) Saponin Test

$1 \mathrm{~mL}$ sample was put into the test tube and added 2 $\mathrm{mL}$ of aquades while shaken for 1 minute, then added 2 drops of $1 \mathrm{~N}$ hydrochloric acid. The positive test is characterized by a stable foam formed.

\section{E. Toxicity Test Using Brine Shrimp Lethality Test Method}

\section{1) Preparation of A. salina Leach larvae}

A gram of A. Salina Leach shrimp is soaked in seawater and illuminated and aerated for 48 hours.

\section{2) Preparation of Test Solutions}

The test solution came from a predetermined fraction and prepared a solution of concentration $0,10.25,50,75$, and $100 \mathrm{ppm}$

\section{3) Toxicity Test}

Prepare a container that has been filled with each of 10 shrimp larvae A. salina aged 48 hours. Each container was then given each solution test with a volume of $6 \mathrm{~mL}$. Furthermore after 24 hours calculated the number of dead shrimp larvae.

\section{RESUlT AND Discussions}

The dichloromethane extract of $P$. alba was separated by using VLC with eluent hexane : ethyl acetate in graduating polarity to obtain 48 fractions. Based on TLC analysis, it was obtained 4 combined fractions namely fractions $\mathrm{A}(1-15)$, $\mathrm{B}(16-30), \mathrm{C}(31-37)$ and D (40-48). Furthermore extracts and each fraction were treated for phytochemical test and the results can be shown in the Table I.

TABLE I. THE RESULT OF PHYTOCHEMICAL TEST OF DICHLOROMETHANE EXTRACT (EDM) AND FRACTION

\begin{tabular}{|c|c|c|c|c|c|}
\hline \multirow{2}{*}{$\begin{array}{l}\text { Secondary } \\
\text { Metabolites }\end{array}$} & \multirow{2}{*}{ EDM } & \multicolumn{4}{|c|}{ Fractions } \\
\hline & & $\mathbf{A}$ & B & $\mathrm{C}$ & D \\
\hline \begin{tabular}{ll}
\multicolumn{2}{l}{ Alkaloid } \\
- & Mayer \\
- & Dragend \\
& orff \\
- & Wagner
\end{tabular} & $\begin{array}{l}+ \\
+ \\
-\end{array}$ & $\begin{array}{l}- \\
- \\
-\end{array}$ & $\begin{array}{l}- \\
- \\
-\end{array}$ & $\begin{array}{l}+ \\
- \\
-\end{array}$ & $\begin{array}{l}- \\
+ \\
+\end{array}$ \\
\hline Flavonoid & - & - & - & - & - \\
\hline Tannin & - & - & - & - & - \\
\hline Phenolic & - & - & - & - & - \\
\hline Steroid & + & + & + & + & - \\
\hline Triterpenoid & - & - & - & - & - \\
\hline
\end{tabular}

In the Table I, it was seemed that dichloromethane extract is known that it contains alkaloids and steroids. While the fraction $\mathrm{A}, \mathrm{B}$, and $\mathrm{C}$ contain steroid. Fraction $\mathrm{C}$ also shows the content of alkaloid in Mayer test but there is no alkaloids for two other reagents. The last fraction D contains alkaloids and then especially taken as a sample for the toxicity test using BSLT method. The result of toxicity test of $\mathrm{D}$ is shown in Table II.

TABLE II. THE RESULT OF TOXICITY TEST FOR FRACTION D

\begin{tabular}{|l|c|c|c|c|c|c|c|}
\hline $\begin{array}{c}\text { Test } \\
\text { Sample } \\
(\mathbf{p p m})\end{array}$ & \multicolumn{3}{|c|}{$\begin{array}{c}\text { Number of } \\
\text { Death }\end{array}$} & \multicolumn{3}{c|}{ \% of Death } & $\begin{array}{c}\text { Average } \\
\text { Number of } \\
\text { Deaths (15) }\end{array}$ \\
\cline { 2 - 7 } & $\mathbf{1}$ & $\boldsymbol{2}$ & $\mathbf{3}$ & $\mathbf{1}$ & $\boldsymbol{2}$ & 3 & 0 \\
\hline 0 & 0 & 0 & 0 & 0 & 0 & 0 & 23,33 \\
\hline 10 & 3 & 2 & 2 & 30 & 20 & 20 & 36,67 \\
\hline 50 & 4 & 3 & 4 & 40 & 30 & 40 & 63,33 \\
\hline 75 & 6 & 7 & 6 & 60 & 70 & 60 & 60 \\
\hline 100 & 7 & 6 & 5 & 70 & 60 & 50 & 90 \\
\hline
\end{tabular}

Based on probit analysis, it is obtained LC50 value of fraction D with $54.448 \mathrm{ppm}$. BSLT method is used to determine the toxicity level of an extract or isolates before the sample is applied to cancer cells treatment. If a sample (e.g. isolate) has a LC50 value to be $<1000 \mathrm{ppm}$, then thus the compound is toxic [5].

\section{CONCLUSION}

The separation of dichloromethane extract was of P. Alba leaf followed by doing phytochemical test was allegedly to contain alkaloids. The fraction containing alkaloid was then treated by toxicity test to yield LC50 value is 54.448 and included as toxic compounds.

\section{REFERENCES}

[1] Perdana, L.T., Vivi.Y.S., Mila. M, "Capability of Cambodian White Flower (Plumeria alba) Essential Oil in Lotion Preparation for Aedes Aegypti Mosquitoes (Daya Rapelan Minyak Atsiri Bunga Kamboja Putih (Plumeria alba) dalam Sediaan Lotion Terhadap Nyamuk Aedes Aegypti)," Laporan Penelitian.Semarang: Sekolah Tinggi Ilmu Farmasi, 2013.

[2] Kumari, S., Mazumder, A., Bhattacharya, S. "In-vitro Antifungal Activity of The Essential Oil of Flowers of Plumeria alba Linn. (Apocynaceae), International Journal of PharmTech Research, 4, 1, 2012, pp 208-212.

[3] Gunawan, PW, D, Ningsih \& M, Aprilia, "Antibacterial and wound healing activities of frangipani extract fractions of frangipani leaves (Plumeria acuminate Ait.) On the skin of rabbits infected with Staphylococcus aureus (Aktivitas antibakteri dan penyembuhan luka fraksi-fraksi ekstrak etanol daun kamboja (Plumeria acuminate Ait.) pada kulit kelinci yang diinfeksi Staphylococcus aureus)," Jurnal Farmasi Indonesia, vol.7, no.2, 2010, pp.73-77.

[4] Gupta M, Mazumder UK, Gomathi P, \& Selvan VT, "Antiinflammatory evaluation of leaves of Plumeria acuminata", BMC Complem. and Alter. Med., 2006, vol.6, pp.36-42.

[5] Meyer, B.N., Ferrigni, N.R., Putnam, J.E., Jacobsen, L.B., Nichols, D.E., dan McLaughin, J.L., "Brine Shrimp: A Convenient General Bioassay for Active Plant Constituent", Planta Medica. 45, 1982, pp 31-34.

[6] Harborne, J. B., "Phytochemical method, London: Chapman and Hall Itd", 1984.

[7] Tiwari, P., Kumar, B., Kaur, M., Kaur, G., Kaur, H, Phytochemical screening and extraction: A Review. International Pharmaceutical Sciencia, 1(1), 2011, pp. 96-106. 